\title{
Religiusitas: Faktor Protektif Pengasuhan Orangtua dengan Status Sosial Ekonomi Rendah
}

\author{
Diany Ufieta Syafitri \\ M. Noor Rochman Hadjam \\ Universitas Islam Sultan Agung \\ Universitas Gadjah Mada \\ Email: dianysyafitri@unissula.ac.id
}

\begin{abstract}
The low family socioeconomic status (SES) often resulted in variety of negative impact towards child development. One of the mechanism how SES affect children is through parenting. In family with low SES, many parents experience stress due to economic pressure that they implement harsh parenting practices. This then leads to various negative impact in children psychological development. One of the most significant protective factor to reduce the negative impact of low SES is religiosity. Based on the dimensions of religiosity, this research tried to capture how religiosity among low SES parents can serve as protective factor. The subjects of this research three low SES parents who considered as religios by local people and their children managed to achieve high education. The research method is quallitative with in-depth interview. The data analysis employed by coding, formulating units of meaning, and categorization. The results showed that based on the five dimensions of religiosity, all three subjects have adequate religious knowledge particularly related to religionbased parenting knowledge, then this followed by intensive and devoted religious ritual, and from experiential dimension they often experience grace and closeness to Allah SWT. The impact of those five dimensions of religiosity is they are able to show many positive virtues which enables them to overcome various obstacles the low SES brought. Those virtues are patience, sincere, nrimo (acceptance), pasrah (surrender), and optimistic. They also then transmitted their religiosity to their children with value internalization and guiding worship rituals.
\end{abstract}

Keywords: low soscioeconomic status, parenting, protective factor, positive virtues, religosity

\section{INTISARI}

Kondisi status sosial ekonomi (SSE) keluarga yang rendah mengakibatkan berbagai dampak negatif pada perkembangan anak. Salah satu mekanisme bagaimana kondisi sosial ekonomi dapat mempengaruhi anak adalah melalui pengasuhan. Pada keluarga dengan SSE rendah, banyak orangtua stres akibat tekanan ekonomi sehingga banyak terjadi praktik pengasuhan yang kasar. Hal ini mengakibatkan berbagai dampak negatif pada perkembangan psikologis anak. Salah satu faktor protektif yang secara signifikan dianggap dapat mengurangi dampak negatif dari kondisi SSE rendah adalah religiusitas. Berdasarkan dimensi-dimensi religiusitas, penelitian ini mencoba menangkap bagaimana religiusitas pada orangtua dengan SSE rendah dapat berfungsi sebagai faktor protektif. Subjek penelitian ini adalah tiga pasang orangtua dengan SSE rendah yang dianggap religius oleh warga sekitar dan anaknya berhasil mencapai pendidikan tinggi. Metode penelitian yang digunakan adalah kualitatif dengan wawancara mendalam. Analisis data penelitian dilakukan dengan koding, merumuskan unit makna, dan kategorisasi. Hasilnya berdasarkan lima dimensi religiusitas, ketiga pasang orangtua tersebut memiliki dimensi pengetahuan agama terutama terkait pengasuhan yang memadai, hal ini kemudian diikuti dengan dimensi ritual ibadah yang intensif dan penuh dengan ketaatan, dari 
segi pengalaman mereka pun seringkali merasakan anugerah dan kedekatan dengan Allah Subhanallahu Wa Ta'ala (SWT). Dampak dari kelima dimensi religiusitas tersebut adalah mereka mampu menunjukkan berbagai karakter positif dalam menjalani kehidupan yang membuat mereka dapat mengatasi berbagai hambatan yang disebabkan oleh SSE rendah. Berbagai karakter positif tersebut adalah sabar, ikhlas, nrimo, pasrah, dan optimis. Mereka juga kemudian melakukan transmisi religiusitas pada anak-anaknya dengan cara penanaman nilai dan mengarahkan ibadah.

Kata kunci: faktor protektif, karakter positif, religiusitas, pengasuhan, sosial ekonomi rendah

$\tau$ ndonesia masih merupakan negara berkembang yang salah satu permasalahannya adalah kondisi ekonomi penduduknya. Menurut Badan Pusat Statistik (BPS, 2015), hingga akhir tahun 2015 lalu jumlah penduduk yang hidup di bawah garis kemiskinan adalah sekitar 28 juta atau sekitar 11\% dari total jumlah penduduk. Trennya pun terus meningkat dari tahun ke tahun (BPS, 2015). Terlebih jika menggunakan Indeks Kemiskinan Multidimensi (IKM), hampir $30 \%$ penduduk Indonesia masih tergolong miskin pada tahun 2014 (Wirawan, 2016). Dari 33 provinsi yang ada, secara mengejutkan Provinsi DIY memiliki angka kemiskinan yang tergolong tinggi, bahkan lebih dari angka kemiskinan nasional (Iskandar, 2014).

Salah satu mekanisme bagaimana status sosial ekonomi (SSE) berdampak pada anak adalah melalui kondisi psikologis orangtua dan pengasuhan yang dilakukan orangtua (Mistry, Vandewater, Huston, \& Mcloyd, 2002). Pengasuhan orangtua dengan SSE rendah telah banyak diteliti dan menunjukkan karakter-karakter yang khas, misalnya ibu-ibu dari kelas pekerja cenderung menganggap kepatuhan sebagai tujuan utama dalam pengasuhan anak, sementara ibu dari kelas sosial yang lebih tinggi melihat kemandirian sama pentingnya dengan kepatuhan (Hoff, Laursen, Tardif, \& Bornstein, 2002). Lebih lanjut banyak penelitian menunjukkan bahwa orangtua dengan SSE rendah cenderung kasar dan menggunakan cara pendisiplinan yang keras (Katz, Corlyon, La Placa, \& Hunter, 2007). Cara pengasuhan yang cenderung keras ini ternyata disebabkan oleh stres dan depresi yang dialami orangtua akibat masalah ekonomi,

sehingga mereka jarang menunjukkan kehangatan pada anak (Katz, dkk., 2007). Padahal, pengasuhan dan cara pendisiplinan yang kasar akan menghasilkan kenakalan remaja (Hollist, Hughes, \& Schaible, 2009). Selain itu, orangtua dengan SSE rendah juga cenderung memiliki aspirasi pendidikan yang rendah bagi anak-anaknya. Hal ini karena mereka berharap anak-anaknya dapat segera membantu mereka untuk bekerja (Walpole, 2003). Kemiskinan dan ketidakamanan ekonomi mempengaruhi kesehatan mental orangtua dan menjadi penyebab penting orangtua menjadi tidak suportif (Magnuson \& Duncan, 2002). Lebih lanjut stres akibat kondisi finansial mempengaruhi efikasi orangtua, dan pengaruh ini dimediasi oleh afek depresi. Orangtua dengan tekanan ekonomi tinggi merasa tidak mampu membuat perubahan positif terhadap anak mereka (Elder, Eccles, Ardelt, \& Lord, 1995).

Di antara banyaknya penelitian yang berfokus berbagai dampak negatif dari SSE rendah terhadap pengasuhan dan perkembangan anak, beberapa penelitian justru menunjukkan anak-anak yang berhasil mencapai pendidikan tinggi meski berasal dari keluarga dengan SSE rendah. Ceballo (2004) mengungkap fenomena di mana terdapat beberapa mahasiswa Latin imigran dan minoritas dengan SSE rendah yang berhasil kuliah di universitas terkemuka di Amerika Serikat. Hasil penelitian tersebut mengidentifikasi empat karakteristik orangtua dengan SSE rendah yang berkontribusi terhadap pencapaian akademis anak, yaitu komitmen orangtua terhadap pentingnya pendidikan, fasilitas orangtua terhadap kemandirian anak, dukungan nonverbal terhadap pencapaian 
tujuan pendidikan, dan kehadiran mentor suportif dari universitas dalam kehidupan mahasiswa. Maton, Hrabowski, dan Grief, (1998) mengungkap hal senada terkait dengan peran keluarga pada keberhasilan akademis laki-laki Afrika Amerika, hasilnya menunjukkan bahwa orangtua mereka sangat berkomitmen dalam keberhasilan akademis anak-anak mereka. Selain itu, orangtua juga memberikan disiplin yang sangat ketat, bahkan disertai dengan hukuman fisik. Meskipun demikian, orangtua juga memberikan cinta, dukungan, komunikasi, dan menjadi model bagi anakanaknya. Faktor lain yang penting adalah hubungan dengan komunitas, misalnya dengan anggota keluarga lain, gereja, aktivitas ekstrakurikuler, teman sebaya, dan guru.

Beberapa penelitian yang lain menunjukkan beberapa faktor yang dapat menjadi faktor protektif bagi berbagai dampak negatif dari SSE rendah. Pertama, dukungan sosial, termasuk dukungan emosi dan instrumental, dapat menjadi faktor protektif terhadap berbagai dampak negatif dari pengaruh tingkat ekonomi (Green \& Rodgers, 2001). Ibu-ibu dengan tingkat SSE rendah yang memiliki sumber dukungan sosial tidak menunjukkan pengasuhan yang kasar dan menghukum dibandingkan dengan ibu yang tidak memiliki dukungan (Hashima dan Amato, 1994). Dukungan sosial dapat meringankan stres yang berkaitan dengan kesulitan ekonomi, dengan memberi orangtua afeksi, pertemanan, dan kesempatan untuk bicara, juga menjadi sumber bantuan dari segi finansial dan pengasuhan anak (Simons, Beaman, Conger, dan Chao, 1993). Jaringan sosial juga dapat memberi informasi dan saran tentang bagaimana mengatur rumah tangga serta pengasuhan anak (Magnuson \& Duncan, 2002).

Selain dukungan sosial, faktor protektif yang lain adalah religiusitas. Beberapa penelitian menunjukkan bahwa pada keluarga dengan SSE rendah religiusitas menjadi faktor protektif yang signifikan. Lichter dan Carmalt (2009) menunjukkan bahwa religiusitas dapat meningkatkan kualitas pernikahan pasangan SSE rendah, di mana pasangan yang memiliki kepercayaan religius yang sama, menghadiri kegiatan religius bersama, dan berdoa bersama memiliki kualitas pernikahan yang tinggi. Brody, Stoneman, \& Flor (1996) juga menemukan hal yang sama, di mana religiusitas orangtua SSE rendah berpengaruh terhadap kondisi keluarga yang lebih dekat, konflik antar orangtua yang lebih sedikit, dan permasalahan anak yang lebih sedikit. Penelitian (Sullivan, 2008) menyatakan bahwa religiusitas dapat menjadi pendukung bagi pengasuhan ibu tunggal dengan SSE rendah. Beberapa penelitian juga menunjukkan bahwa religiusitas dapat menjadi faktor protektif terhadap peristiwa penuh tekanan (Pargament dkk., 1990). Hasil penelitian (Joshi, Hardy, \& Hawkins, 2009) menunjukkan bahwa secara umum di Amerika Serikat, religiusitas dapat menjadi faktor protektif bagi orangtua dengan SSE rendah, religiusitas dapat meningkatkan perilaku pengasuhan yang positif terhadap anak.

Religiusitas didefinisikan sebagai kondisi di mana seseorang mempercayai Tuhan, yang ditunjukkan melalui kesalehan dan keterlibatannya dalam agama. Semakin tinggi kesalehan dan keterlibatannya, semakin besar pula kepercayaannya terhadap Tuhan dan semakin tinggi religusitasnya (Salleh, 2012). Untuk mengetahui religiusitas orangtua dengan SSE rendah yang anaknya berhasil mencapai pendidikan tinggi, penelitian ini menggunakan kerangka dimensi religiusitas yang dikemukakan oleh Stark dan Glock (1968) yang kemudian dimodifikasi (Elmenouar, 2014) untuk lebih disesuaikan dengan konteks Islam. Menurut Stark dan Glock (1968) dimensi religiusitas adalah dimensi ideologis (kepercayaan), ritual (sub dimensi ritual dan ketaatan), pengalaman, pengetahuan, dan konsekuensi. Mengacu pada lima dimensi tersebut, El Menouar dan Stiftung (2014) memodifikasinya menjadi dimensi-dimensi berikut ini: 1) belief (kepercayaan) yaitu terkait dengan keimanan seseorang terhadap Tuhan atau dalam hal ini adalah Allah SWT dan rukun iman yang lain; 2) ritual dalam hal ini terkait dengan ritual peribadatan yang dalam Islam contohnya adalah salat lima 
waktu, berzakat, puasa, dan ibadah lain yang bersifat wajib maupun sunah; 3) devotion atau ketaatan, yang terkait dengan ritual peribadatan pribadi seperti berdzikir dan berdoa yang ditinjau dari frekuensi dan intensitasnya; 4) pengalaman, menurut Stark dan Glock (1968) mengasumsikan bahwa seseorang yang religius akan mengalami perasaan religius yang terjadi saat seseorang berkomunikasi dengan suatu hal yang supernatural. Termasuk dalam hal ini adalah merasakan kehadiran Allah dan merasakan hukuman atau anugerah dari Allah; 5) pengetahuan, dalam setiap agama penguasaan atas pengetahuan agama sangat diharapkan. Dalam Islam, pengetahuan agama terkait dengan isi dari Quran dan hadis. Di sisi lain menurut Tilliouine \& Belgoumidi (2009), dimensi religiusitas dalam Islam mencakup dimensi 1) kepercayaan/keimanan, 2) praktik ritual ibadah, 3) altruisme yaitu terkait hubungan relasional dengan orang lain, dan 4) pengayaan pengetahuan agama dan pengalaman spiritual.

Hubungan antar dimensi religiusitas dalam Islam seringkali dianalogikan dengan pohon, di mana kepercayaan (keimanan) terhadap Allah SWT atau sering disebut tauhid merupakan akarnya, kemudian peraturan-peraturan (termasuk di dalamnya ritual ibadah, ketaatan, dan pengetahuan) adalah batangnya, dan yang menjadi buahnya adalah kebaikan atau disebut juga dengan akhlak (Salleh, 2012). Faktor protektif adalah karakteristik yang dapat meningkatkan proses adaptasi (Martinez-Torteya, Bogat, Eye, Von, \& Levendosky, 2009). Lebih lanjut, faktor protektif adalah kondisi atau atribut individu, keluarga, komunitas, atau masyarakat yang lebih luas yang memitigasi risiko dan meningkatkan perkembangan yang sehat dan sejahtera, atau sederhananya faktor protektif adalah kekuatan-kekuatan yang membantu menjadi perisai serta mendukung keluarga yang berada dalam risiko (Child Welfare Information Gateway, 2014).

\section{Metode Penelitian}

Metode penelitian yang digunakan adalah kualitatif yang dianggap sebagai metode yang tepat untuk memeriksa suatu fenomena yang tidak banyak diketahui dengan pendekatan fenomenologi. Fenomenologi dapat diartikan sebagai penelitian dengan melibatkan pengalaman subjektif manusia dan bagaimana manusia mampu menginterpretasikan pengalamannya (Moleong, 2007). Dalam penelitian kualitatif, kemungkinan untuk menghasilkan penemuan baru dan pemahaman atas kondisi kontekstual yang ada dapat dilakukan, sehingga menjadi suatu kesempatan untuk menyuarakan kondisi populasi-populasi yang unik (Maton, Hrabowski, dan Greif, 1998).

\section{Partisipan}

Penelitian kualitatif menggunakan purposeful sampling, yaitu pemilihan partisipan yang disesuaikan dengan masalah dan fenomena yang diteliti. Kriteria partisipan dalam penelitian ini adalah orangtua dengan status sosial ekonomi rendah yang memiliki anak yang berhasil mencapai pendidikan tinggi, yaitu sebagai berikut:

1. Status sosial ekonomi rendah

Menurut Bank Dunia dan BPS, orangtua miskin memiliki rata-rata lama pendidikan 5,9 tahun atau setara dengan SD atau tidak tamat SD. Untuk jenis pekerjaan, orangtua miskin adalah mereka yang bekerja di sektor informal dan jumlah penghasilan keluarga menurut MDG's (Stalker dkk, 2007), adalah yang berjumlah di bawah $\$ 1$ hingga $\$ 2$ per harinya.

Dari data di atas, maka kriteria untuk status sosial ekonomi rendah adalah orangtua yang:

a. Memiliki pendidikan di bawah
SD hingga SMA
Memiliki pekerjaan di sektor
informal
c. Memiliki penghasilan per hari
di bawah $\$ 1$ hingga $\$ 2$ (di
bawah Rp 10.000-20.000)

2. Anak yang dapat mencapai pendidikan tinggi

Pendidikan tinggi yang dimaksud di sini adalah mereka yang setidaknya dapat mengikuti pendidikan di perguruan tinggi untuk jenjang strata 1 , baik negeri maupun 
swasta. Ada 3 orang partisipan yang terlibat dalam penelitian ini.

\section{Prosedur Penelitian}

Penelitian yang dilakukan menggunakan metode wawancara, yaitu merupakan praktik memahami orang lain dengan bicara dan mendengarkan (Petersen \& Willig, 2002). Lebih lanjut, wawancara adalah tanya jawab yang diarahkan untuk mencapai tujuan tertentu. Wawancara kualitatif bertujuan untuk mengetahui makna subjektif yang dimengerti seseorang terkait dengan topik yang diteliti (Poerwandari, 2005). Ada berbagai jenis wawancara, jenis wawancara yang digunakan dalam penelitian ini adalah wawancara semi terstruktur. Dalam wawancara jenis ini, pewawancara telah mendapat gambaran teoretis dari partisipan dan pengalaman yang diteliti. Oleh karena itu, pewawancara telah menyiapkan pedoman wawancara yang umum mengenai aspek-aspek yang harus dibahas. Wawancara ini dapat terfokus pada aspek tertentu dan dapat bersifat mendalam (Poerwandari, 2005).

\section{Analisis Data}

Analisis data dalam penelitian kualitatif adalah mempersiapkan dan mengorganisasi data untuk dianalisis, kemudian mereduksinya menjadi tematema melalui proses koding dan pemadatan kode-kode, lalu terakhir menunjukkan data dalam tabel atau diskusi (Creswell, 2013).

Berikut adalah deskripsi subjek penelitian:

\section{Hasil Penelitian}

Tabel 1 Deskripsi subjek penelitian

\begin{tabular}{ccccccc}
\hline \multirow{2}{*}{ Keterangan } & \multicolumn{2}{c}{ Subjek 1 } & \multicolumn{2}{c}{ Subjek 2 } & \multicolumn{2}{c}{ Subjek 3 } \\
& Ayah & Ibu & Ayah & Ibu & Ayah & Ibu \\
\hline Pendidikan & SMK & SMK & SMP & SD & SMK & SMK \\
Pekerjaan & Buruh & Buruh & Buruh & Buruh & Buruh & Buruh \\
& tani & tani & tani & tani & tani & tani \\
Penghasilan/bula & $300-700$ & $300-700$ & $300-900$ & $300-900$ & $300-900$ & $300-900$ \\
$n$ & ribu & ribu & ribu & ribu & ribu & ribu \\
\hline
\end{tabular}

\section{Hasil Analisis Data}

Berdasarkan hasil analisis data yang dilakukan, maka secara umum didapatkan hasil berikut ini

1. Religiusitas orangtua Berdasarkan hasil pengumpulan data, maka didapatkan dimensi-dimensi religiusitas berikut ini:

a. Dimensi belief (kepercayaan) Dimensi ini berkaitan dengan keimanan seseorang terhadap Allah SWT. Berdasarkan hasil analisis data, ditemukan bahwa ketiga subjek memiliki kepercayaan bahwa Allah SWT adalah Dzat yang memelihara ciptaan-Nya baik dalam memberi rezeki, mengabulkan doa, memberi jalan keluar, dan memiliki rencana yang terbaik. “...sabar aja, kalo orang sabar nanti diberi rezeki oleh Allah yang lebih banyak" (S1, A1, L52-53)

"Masalah rezeki insyaAllah, kita kalo memang niat insyaAllah ada jalan" (S2, A2, L4)

"Rezeki itu nggak cuma di pabrik, 1000 rezeki itu Allah Maha Tahu dan Maha Kaya, betul Ayahnya itu pokoknya gitu mbak prinsipnya. Saya ya cuma berdoa. Ya kita berdoa dan berusaha disamain nanti kan Allah memberi jalan. Gitu mbak, cuma pedoman saja gitu mbak sampai sekarang." (S1, A2, L4-7) 
"Tapi nek diterima Allah pasti kasih jalan. Aku percaya Allah pasti kasih jalan" (S3, A2, L37-38)

b. Dimensi pengetahuan

Pengetahuan dalam hal ini berkaitan dengan pengetahuan tentang agama. Dalam hal ini ditemukan bahwa ketiga pasangan subjek 1, 2, maupun 3 , semuanya tampak memiliki pengetahuan pengasuhan yang memadai, terutama berdasarkan tuntunan Islam. Subjek 1 memaparkan bahwa sejak awal melakukan hubungan seksual pun sesuai dengan tuntunan agama.

"dari pertama ya, waktu pokoknya kita dari pertama tu kita mau memproses tu berdoa kepada Allah. Supaya besok itu saya diberi keturunan anak yang sholeh atau sholehah. Kalau perempuan sholehah, kalo laki-laki sholeh. Kalo selesai coitus ya, bersetubuh itu harus kita cuci ya, wudhu, setelah itu kita berdoa" (S1, A1, L1-4)

Selama periode kehamilan pun janin banyak dibacakan $\mathrm{Al}$ Quran, begitu lahir diperdengarkan adzan, dan setelah lahir juga banyak diperdengarkan Al Quran serta memberikan air susu ibu (ASI) sesuai sunah rasul.

"Terus nganu setelah lahir, baru bayi lahir itu sebaiknya kita azani. Yang telinga kanan itu qomati, nah telinga yang kiri biar dia itu mendengar suara azan kalo disuruh salat mau, walau nggak mendengar suara azan sulit, iya to? Terus setelah itu kita di ASI sendiri aja. Kan saya nggak jadi pegawai ya, saya cuma buruh ya, saya beri ASI. Sampai umur pas 2 tahun saya beri ASI terus. Terus selama memberi ASI tu ayo doa minum juga dikasih terus, diajarin terus" (S1, A1, L11-16)

Setelah lahir, pengasuhan yang dilakukan pun didasarkan pada agama, sehingga perlu melaksanakan kewajiban orangtua sesuai dengan tuntunan agama, termasuk memberi kasih sayang, memberi contoh, dan memastikan bahwa makanan yang dimakan halal.

"Yang namanya anak dan orangtua itu dasarnya satu, agama. Ini satu dasar yang penting adalah agama." (S2, A1, L1-2)

"Memberi contoh, menuntun, mendorong, untuk menggapai cita-cita itu udah kewajiban orangtua" (S2, A1, L3-4)

"Perhatian itu kalo yang buat pedoman itu dasarnya agama. Kita tu sebagai orangtua harus mengerti kewajibannya orangtua tu bagaimana terhadap anak. Melindungi, memberi nafkah, itu harus wajib. Dan mencontoh. Dari kecil diberi contoh. Diberi tahu, diberi tahu ini kewajibannya begini. Nah ini kembali kepada unsur orangtua yang tidak tahu agama jadinya lain." (S2, A63, L1-4)

c. Dimensi ritual ibadah dan ketaatan

Ritual ibadah dalam hal ini berkaitan dengan ritual ibadah dalam Islam yaitu salat, puasa, 
sedekah, dan lain-lain. Ketaatan dalam hal ini terkait dengan intensitas dan frekuensi dalam menjalankan ibadah tersebut. Dalam hal ini, ditemukan bahwa semua subjek melakukan berbagai ritual ibadah wajib dan sunah yang dilakukan secara intensif. Mereka pun mengiringi pertumbuhan anak dengan doa, seperti saat hamil, orangtua mendoakan, membacakan Al Quran, dan berdzikir.

"Semenjak maknya mulai
mengandung dari yang
anak pertama sampai
anak yang kedua,
pokoknya sejak mulai
mengandung, kita tu
selalu berdoa semoga
anak ini menjadi anak
yang baik menurut
agama. Dan ini kalo
budaya orang kita, setiap
suami istri kalo istrinya
mengandung diutamakan
kita itu baca Fatihah di
depannya orang yang
mengandung itu." (S2, A7,
L1-4)
"Dan setelah lahir lahir itu
anak, kita ngaji baca Al
Quran, anaknya kita
pangku. Mungkin dia
masih apal tu kalo belum
mau tidur kita baca dzikir
agama itu. Orang-orang
ngaji itu, hafalan huruf
hijaiyyah. Itu pake lagu,
itu sampai dia udah kita
lama nyanyi gitu dia baru
tidur. Itu karena yang kita
perdengarkan pertama
adalah syair ilmu.
InsyaAllah anaknya itu
pikirannya jatuhnya ke
ilmu itu." (S2, A7, L5-8)

Selain itu bentuk ritual ibadah dari para subjek adalah melaksanakan ibadah sunnah seperti salat tahajjud dan dhuha, puasa senin dan kamis, dan membaca Al Quran. Hal ini pun dilakukan dengan frekuensi yang intensif yaitu setiap hari.

"Dan kita harus tu selalu kalo malem tu sholat tahajjud anak kita bangunkan. Harus bangun walaupun istilahnya dia marah. Tapi dia mau, nanti dia kan terus terbiasa." (S1, A2, L28-29) "kalo pagi tu sholat dhuha walaupun 2 rakaat itu kan minta rezeki kepada Allah." (S1, A2, L 41)

"Dan alhamdulillah prihatin, diajarin puasa. Senin-Kamis tu kan kita prihatin ya." (S1, A2, L45) "anak-anakku tak suruh kamis, senin itu puasa terus anu kalo dia punya ya alhamdulillah kalo punya rezeki ra ketang sitik ki ngenehi kancane." (S3, A5, L4-5)

Ibadah sedekah ini ditekankan oleh ketiga subjek baik kepada diri sendiri maupun anakanaknya. Bentuk ibadah lainnya yang dilakukan adalah orangtua mencari ilmu agama dan mendoakan anak.

d. Dimensi pengalaman

Pengalaman di sini terkait dengan pengalaman merasa dekat dengan Allah SWT dan merasa mendapatkan hukuman ataupun anugerah dari Nya. Dalam hal ini, para subjek memiliki beberapa pengalaman mendapatkan anugerah dari Allah SWT, yaitu terkait rezeki berupa makanan dan anakanaknya yang mendapatkan beasiswa untuk kuliah.

"Alhamdulillah pas pulang tu ada tamu betul itu 
Allah memberi makanan seperti yang diinginkan, banyak itu. Allah tu Maha Mengetahui dan Allah tu Maha Kaya. Iya mak, iya mak, saya nggak mau ingin kok sama itu kita harus seperti itu" (S1, A1, L54-56)

"Yo mungkin ya Allah ki kan Maha Mendengar, Maha Segalanya yo mbak. mungkin penderitaanpenderitaan sing tak alami dari kecil itu mungkin yo menghasilkan buah ya sekarang itu mungkin fajar walaupun toh mungkin masih sekolah tapi insyaAllah Gusti Allah itu ngasih jalan yang lancar untuk ngeraih itu to mbak" (S3, A2, L26-29)

2. Religiusitas dan karakter positif

Terdapat berbagai karakter positif yang muncul sebagai dampak religiusitas para subjek. Berbagai karakter positif tersebut adalah kesabaran, menerima, ikhlas, optimis, pasrah, dan berprasangka baik terhadap rencana Allah.

"Tur iling oh Allah paring ngene, iling, oh Allah paring ngene, sabar. Wo yo aku tekan sak mene, wes tak usahake tekan sak mene. Allah tekan sak mene. Gitu. Pokoknya iling, sabar, narimo. Kayak gitu. Iya kalo nggak sabar, nggak iling, nggak narimo pada Allah kita tu dimurkai. Menungsa, menungsa ki." (S1, A2, L55-58)

"Ya pokoknya kita niatkan ki beribadah gitu mbak. kita ikhlas, Allah akan memberi sesuatu pada orangtua apa anaknya, apa siapa. Nggak sekarang yo besok. Kalo saya ngajari tu ya karena saya mencari jalan Allah tu ya rezeki pun karena Allah. Ya alhamdulillah dengan keikhlasan tu karena Allah. Allah memberi ya alhamdulillah Allah memberi jalan pada anak saya. Kurang mampu anak saya bisa belajar apa yang bisa gitu." (S1, A2, L 61-65)

"Yang penting hari ini seperti ini kita lakukan seperti ini. Untuk besok kita nggak tau Allah yang ngatur. Ya kita percaya aja kalo bener bener ya maksude yakin besok itu memang segala sesuatu yang ditentukan Allah ya kita yakin aja. Nggak usah harus dipaksakan lah istilahe gitu. Jadi alurnya cerita Allah aja lah yang ini nentukan. Kita cuma njalanin aja. Ya dah ada dalangnya. Kita dalangnya ya Allah itu tadi" (S3, A10, L1-5)

"Kalo udah dasar agama insyaAllah apapun yang dituju dengan niat yang kuat disesuaikan dengan kemampuan dibarengi doa insyaAllah ada jalan. Terkabul enggaknya bukan urusan kita. Urusan yang Maha Kuasa. Kita hanya bisa berusaha." (S2, A1, L4-6)

3. Transmisi religiusitas pada anak

Selanjutnya, religusitas dan karakter positif para subjek juga ditransmisikan kepada anak dengan berbagai metode pembiasaan, yaitu mengajarkan anak berdoa, salat, puasa, dan memberikan contoh dalam melaksanakan berbagai ibadah.

"Iya. Kan mencontohi to. Upamane kita sholat. Nyuruh anak sholat, masak saya nggak sholat? Iya to? Ayo sholat. Bangun, sholat tahajjud. Saya sudah wudhu siap mau pake rukuh, iki mamak siap gek tangi. Udah sholat, kok belum bangun, ayo selak ke enthek an wektu kowe udah mau selesai kok belum? Terus dia tangi. Dia tu 
bangun. Dengan mencontohi mbak." (S1, A6, L 1-4)

"Ya berangkat bareng, ngaji. Berangkat bareng ke masjid. Jadi kalo kita hanya nyuruh, kita nggak berangkat ya mana mungkin anak mau jalan. Sampai musim tarawih kalo sholat juga bareng. Pulang, tadarus, bareng. Semuanya. Yang nggak tadarus nyimak. Jadi anak itu ada orangtua begini, mesti anak ikut." (S2, A9, L1-4)

\section{Pembahasan}

Berdasarkan pemaparan hasil di atas, dapat dilihat bahwa para subjek tampak memiliki religiusitas yang tinggi. Pertama, hal ini terlihat dari kepercayaan atau keimanan mereka terhadap Allah SWT, seperti halnya dalam rukun iman yang pertama. Dalam hal ini terutama adalah kepercayaan terkait Allah sebagai Maha Pemberi Rezeki dan bahwa Allah Maha Memberi Pertolongan. Kepercayaan ini termasuk dalam tauhid rububiyah, di mana seorang muslim percaya bahwa Allah adalah yang memelihara-Nya, termasuk memberi rezeki, memberi jalan keluar, dan lain sebagainya (Philips, 2005).

Kedua, hal ini terlihat dalam dimensi ritual ibadah dan ketaatan (frekuensi dan intensitas). Sesuai dengan Rukun Islam, yaitu melakukan salat, zakat, dan puasa, para subjek pun tidak hanya mengerjakan ibadah wajib saja, tetapi juga ibadah sunah yang dianjurkan (sunnah ghairu muakkad) seperti salat tahajjud, puasa sunnah, bersedekah, berdzikir, membaca Al Quran, dan pergi ke masjid. Para subjek pun menjalankan ibadah ini dengan intensitas dan frekuensi yang tinggi, yaitu setiap hari. Pada dimensi pengalaman, mereka pun memiliki beberapa pengalaman di mana mereka mendapatkan berbagai anugerah dari Allah SWT baik berupa rezeki, makanan, dan lain sebagainya. Dalam mengasuh anak, para subjek memiliki pengetahuan yang memadai tentang cara mengasuh anak sesuai dengan tuntunan agama Islam, di mana Islam memiliki anjuran-anjuran yang sebaiknya dilakukan sejak janin hingga lahir.

Seperti disinggung di awal, buah dari keimanan, pengetahuan agama, dan ketaatan dalam beribadah adalah akhlak atau karakter yang baik, yang berasal dari keimanan terhadap Allah SWT (Krauss dkk., 2005). Hal ini juga terlihat dari dampak religiusitas subjek, di mana mereka dapat menunjukkan beragam karakter positif atau akhlak dalam menjalani kehidupan seharihari. Ini juga sesuai dengan tambahan dimensi religiusitas menurut Stark dan Glock (1968), yaitu dimensi konsekuensi, yaitu pengaruh atas dimensi kepercayaan, ketaatan, ritual, dan pengetahuan terhadap kehidupan sehari-hari.

"Tur iling oh Allah paring ngene, iling, oh Allah paring ngene, sabar. Wo yo aku tekan sak mene, wes tak usahake tekan sak mene. Allah tekan sak mene. Gitu. Pokoknya iling, sabar, narimo. Kayak gitu. Iya kalo nggak sabar, nggak iling, nggak narimo pada Allah kita tu dimurkai. Menungsa, menungsa ki." (S1, A2, L55-58)

Kutipan subjek 1 di atas menunjukkan berbagai karakter positif dalam menjalani kehidupan yaitu kesabaran dan penerimaan atas takdir Allah SWT.

"Yang penting hari ini seperti ini kita
lakukan seperti ini. Untuk besok kita
nggak tau Allah yang ngatur. Ya kita
percaya aja kalo bener bener ya
maksude yakin besok itu memang
segala sesuatu yang ditentukan Allah
ya kita yakin aja. Nggak usah harus
dipaksakan lah istilahe gitu. Jadi
alurnya cerita Allah aja lah yang ini
nentukan. Kita cuma njalanin aja. Ya
dah ada dalangnya. Kita dalangnya ya
Allah itu tadi" (S3, A10, L1-5)

Demikian pula kutipan dari subjek 2 di atas juga menunjukkan adanya kepasrahan dan penerimaan terhadap takdir Allah SSE. Meskipun sabar, pasrah, dan menerima ketentuan Allah SWT, tetap terlihat adanya usaha yang maksimal dan 
optimisme terhadap masa depan seperti yang dikatakan oleh subjek 3 di bawah ini.

"Kalo udah dasar agama insyaAllah
apapun yang dituju dengan niat yang
kuat disesuaikan dengan kemampuan
dibarengi doa insyaAllah ada jalan.
Terkabul enggaknya bukan urusan
kita. Urusan yang Maha Kuasa. Kita
hanya bisa berusaha." (S2, A1, L4-6)

Melaksanakan berbagai ibadah seperti salat, puasa, zakat, haji merupakan usaha untuk mendidik kepribadian, membersihkan jiwa, mengajarkan berbagai kebiasaan yang baik. Ini akan membantu seseorang dalam memikul berbagai beban kehidupan dan membantu membentuk kepribadian yang baik, yang pada akhirnya dapat menumbuhkan kesehatan mental. Bermacam-macam ibadah dalam Islam menempa penganutnya untuk mengontrol hawa nafsu, memperkuat kemauan, meningkatkan interaksi positif dengan orang lain. Di samping itu, mendekatkan diri pada Allah SWT dengan berbagai ritual ibadah juga dapat memunculkan beragam perasaan positif seperti bahagia dan tenang (Najati, 2005a). Berbagai penelitian juga menunjukkan adanya hubungan positif antara religiusitas dengan berbagai aspek kehidupan, seperti kesehatan mental dan kesehatan fisik (Koenig, 2004), mencegah, mengatasi, dan menyelesaikan konflik pernikahan (Lambert \& Dollahite, 2006), serta kepuasan hidup dan kebahagiaan (Lun \& Bond, 2013).

Secara lebih spesifik, berbagai ritual ibadah yang dilakukan oleh para subjek juga menimbulkan berbagai dampak positif. Penelitian menunjukkan bahwa kualitas dzikir berkorelasi dengan kelapangdadaan seseorang (Nashori, 2005). Demikian pula dengan ibadah yang lain seperti salat, puasa, dan sedekah memberi dampak positif terhadap kesehatan fisik dan jiwa (Najati, 2005b). Dampak religiusitas yang berupa berbagai karakter positif (akhlak) juga membuat manusia lebih tangguh dalam menjalani kehidupan. Penelitian dari Curry, Price, dan Price (2008) menunjukkan bahwa orang yang sabar lebih kooperatif, demikian juga penelitian dari Clements dan Ermakova (2012) menujukkan bahwa seseorang yang pasrah (surrender) terhadap Tuhan cenderung memiliki stres dan kecemasan yang lebih rendah sehingga juga menurunkan risiko masalah kesehatan yang terkait dengan stres.

Berdasarkan gambaran di atas, dapat dilihat bahwa religiusitas dapat menjadi faktor protektif, dalam hal ini menjadi kondisi atau atribut keluarga dengan SSE rendah dari berbagai stresor dan faktor risiko lainnya. Stresor utama orangtua dengan SSE rendah adalah tekanan ekonomi, pemasukan yang tidak pasti, dan pekerjaan yang tidak stabil, sehingga membuat mereka kesulitan membayar pengeluaran bulanan. Tekanan-tekanan ini berkaitan dengan konflik pernikahan, depresi, dan pengasuhan yang tidak tepat (Conger dkk., 1992). Dari hasil penelitian ini, para subjek dalam penelitian ini tidak menunjukkan gejala stres, depresi, ataupun masalah dalam pernikahan. Kepercayaan mereka terhadap Allah SWT sebagai Maha Memberi Rezeki membuat mereka tetap berusaha maksimal, pasrah, sekaligus optimis terhadap tekanan ekonomi dan masa depan keluarga. Hal ini sesuai dengan hasil penelitian (Pargament dkk., 1990) bahwa cara coping religius berupa percaya terhadap kasih sayang Tuhan, merasa Tuhan sebagai mitra yang suportif dalam menghadapi tekanan, dan melakukan berbagai ritual ibadah memberikan dampak yang lebih positif pada kondisi psikologis. Penelitian (Wiley, Warren, \& Montanelli, 2002) juga menunjukkan bahwa orangtua yang lebih religius melaporkan penggunaan strategi pengasuhan yang lebih adaptif dan mengalami peristiwa penuh tekanan yang lebih sedikit.

Religiusitas orangtua yang lebih besar juga akan menguatkan keberatan hubungan keluarga, konflik antar pasangan yang lebih rendah, dan masalah psikologis yang lebih rendah pada anak (Brody, Stoneman, \& Flor, 1996). Penelitian (Sullivan, 2008) menunjukkan bahwa Ibu tunggal dengan SES rendah bersandar pada keimanan dan ibadah dalam pengasuhan. Peran penting agama, terutama dalam dimensi keimanan, cara pandang, dan ritual ibadah adalah untuk menghadapi tantangan dalam pengasuhan. Para orangtua tersebut tidak memiliki teladan dalam pengasuhan, 
sehingga mereka kembali pada Tuhan untuk meminta pertolongan. Lebih spesifik, doa atau ritual ibadah lain membuat ibu dengan SES rendah merasa lebih kuat dan nyaman sehingga membuat mereka mengasuh anak secara lebih sabar dan efektif.

Lebih lanjut, dapat dilihat adanya usaha orangtua untuk mentransmisikan religiusitasnya terhadap anak-anak. Hal ini terutama dilakukan dengan memberi contoh seperti pada kutipan S1, A6, L 1-4 dan S2, A9, L1-4 di atas. Penelitian menunjukkan bahwa religiusitas orangtua memprediksi religiusitas pada anak dan remaja, tidak diperlukan dukungan orangtua dan interaksi antara orangtua dan anak agar transmisi berhasil (Leonard, Cook, Boyatzis, Kimball, \& Flanagan, 2013). Lebih lanjut, Patacchini dan Zenou (2011) menunjukkan bahwa keberhasilan religiusitas secara langsung dipengaruhi oleh usaha orangtua untuk mensosialisasikan nilai-nilai keagamaan. Hal ini dapat dilihat dari usaha para subjek untuk melakukan sosialisasi baik pada nilai agama maupun ritual ibadah pada anakanaknya terutama melalui memberikan contoh dan terus menerus mendorong anak untuk melakukan ritual ibadah.

\section{Simpulan Dan Saran}

Temuan dalam penelitian ini menunjukkan bahwa orangtua dengan SSE rendah menunjukkan religiusitas yang tinggi, yang terlihat dari berbagai dimensi religiusitas yang digunakan. Tidak hanya itu, dampak dari religiusitas ini adalah munculnya berbagai karakter positif atau akhlak yang kemudian menjadi faktor protektif bagi para subjek untuk mengatasi berbagai tantangan dalam kondisi SSE yang rendah. Para orangtua juga kemudian berusaha untuk mentransmisikan religiusitasnya pada anak-anaknya. Penelitian ini menunjukkan bahwa religiusitas berperan penting dalam menjadi faktor protektif bagi orangtua dengan SSE rendah. Keterbatasan penelitian ini adalah terbatasnya jumlah subjek dalam penelitian, sehingga di waktu yang akan datang masih diperlukan jumlah partisipan yang lebih banyak dan menggunakan metode kuantitatif untuk mendapatkan data yang lebih banyak, sehingga akan didapatkan kesimpulan yang lebih kuat.

\section{Daftar Pustaka}

BPS. (2015). Persentase penduduk miskin maret 2015 mencapai 11.22\%. Diunduh dari https://www.bps.go.id/Brs/view/id/ $\underline{1158}$

Brody, G. H., Stoneman, Z., \& Flor, D. (1996). Parental religiosity, family processes, and youth competence in rural, twoparent African American families. Developmental psychology, 32(4), 696. http://doi.org/10.1037/00121649.32.4.696

Ceballo, R. (2004). From barrios to Yale: The role of parenting strategies in Latino families. Hispanic Journal of Behavioral Sciences, 26(2), 171-186. https://doi.org/10.1177/073998630 $\underline{4264572}$

Child Welfare Information Gateway. (2014). Protective factors approaches in child welfare. Washington, DC: U.S. Department of Health and Human Services

Clements, A. D., \& Ermakova, A. V. (2012). Surrender to god and stress: A possible link between religiosity and health. Psychology of Religion and Spirituality, $\quad 4(2), \quad 93$. http://doi.org/10.1037/a0025109

Conger, R. D., Conger, K. J., Elder, G. H., Lorenz, F. O., Simons, R. L., \& Whitbeck, L. B. (1992). A family process model of economic hardship and adjustment of early adolescent boys. Child development, 63(3), 526541. http://doi.org/ 10.1111/j.14678624.1992.tb01644.x

Creswell, J. W. (2013). Research design: Qualitative, quantitative, and mixed methods approaches. London: Sage publications. 
Curry, O. S., Price, M. E., \& Price, J. G. (2008). Patience is a virtue: Cooperative people have lower discount rates. Persona, 44, 778-783. http://doi.org/10.1016/j.paid.2007.0 9.023

Elder Jr, G. H., Eccles, J. S., Ardelt, M., \& Lord, S. (1995). Inner-city parents under economic pressure: Perspectives on the strategies of parenting. Journal of Marriage and the Family, 771-784.

El-Menouar, Y. (2014). The five dimensions of muslim religiosity. Results of an Empirical Study. Methods, Data, Analyses, $\quad 8(1), \quad 26$. http://doi.org/10.12758/mda.2014.0 03

Green, B. L., \& Rodgers, A. (2001). Determinants of social support among low-income mothers: A longitudinal analysis. American Journal of Community Psychology, 29(3), 419441.

http://doi.org/10.1023/A:10103718 30131

Hashima, P. Y., \& Amato, P. R. (1994). Poverty, social support, and parental behavior. Child Development, 65(2), 394-403. http://doi.org/10.1111/j.14678624.1994.tb00758.x

Hoff, E., Laursen, B., Tardif, T., \& Bornstein, M. (2002). Socioeconomic status and parenting. Handbook of parenting Volume 2: Biology and ecology of parenting, $8(2), 231-52$.

Hollist, D. R., Hughes, L. A., \& Schaible, L. M. (2009). Adolescent maltreatment, negative emotion, and delinquency: An assessment of general strain theory and family-based strain. Journal of Criminal Justice, 37(4), 379387.

https://doi.org/10.1016/j.jcrimjus.20 $\underline{09.06 .005}$

Iskandar, Y. (2014, November 6). Angka kemiskinan di DIY masih tinggi.
Tribun News. Diunduh dari http://www.tribunnews.com/regiona l/2014/11/06/angka-kemiskinan-didiy-masih-tinggi

Joshi, P., Hardy, E., \& Hawkins, S. (2009). Role of religiosity in the lives of the low-income population: $A$ comprehensive review of the evidence role of religiosity in the lives of the lowincome population: A comprehensive review of the evidence final report. Washington DC: US Department of Health and Human Services.

Katz, I., Corlyon, J., La Placa, V., \& Hunter, S. (2007). The relationship between parenting and poverty. New York: Joseph Rowntree Foundation.

Koenig, H. G. (2004). Religion, spirituality, and medicine: Research findings and implications for clinical practice. Southern Medical Association, 97(12), 1194-1200.

Krauss, S., Hamzah, A., Suandi, T., Noah, S., Mastor, K., Juhari, R., ... Manap, J. (2005). The muslim religiositypersonality measurement inventory (MRPI)'s religiosity measurement model: Towards filling the gaps in religiosity research on muslims. Pertanika Journal of Scoail Science and Humanity, 13(2), 131-145.

Lambert, N. M., \& Dollahite, D. C. (2006). How religiosity helps couples prevent, resolve, and overcome marital conflict. Family Relations, 55(4). http://doi.org/10.1111/j.17413729.2006.00413

Leonard, K. C., Cook, K. V, Boyatzis, C. J., Kimball, C. N., \& Flanagan, K. S. (2013). Parent-child dynamics and emerging adult religiosity: Attachment, parental beliefs, and faith support. Psychology of Religion and Spirituality, 5(1), 5-14. http://doi.org/10.1037/a0029404

Lichter, D. T., \& Carmalt, J. H. (2009). Religion and marital quality among 
low-income couples. Social Science Research, 38(1), 168-187.

Lun, V. M., \& Bond, M. H. (2013). Examining the relation of religion and spirituality to subjective well-being across national cultures. Psychology of Religion and Spirituality, 5(4), 304315. http://doi.org/10.1037/a0033641

Magnuson, K. A., \& Duncan, G. J. (2002). Parents in poverty. Handbook of parenting, 4, 95-121.

Martinez-Torteya, C., Bogat, G. A., Eye, A. Von, \& Levendosky, A. A. (2009). Resilience Among children exposed to domestic violence: The role of risk and protective factors resilience. Child Development, 80(2), 562-57. http://doi.org/10.1111/j.14678624.2009.01279.x

Maton, K. I., Hrabowski, F. A., \& Greif, G. L. (1998). Preparing the way: A qualitative study of high-achieving African American males and the role of the family. American Journal of Community Psychology, 26(4), 639668.

Mistry, R. S., Vandewater, E. A., Huston, A. C., \& Mcloyd, V. C. (2002). Economic well-being and children' $s$ social adjustment: The role of family process in an ethnically diverse lowincome sample. Child Development, 73(3), 935-951.

Moleong, L. J. (2007). Metodologi penelitian kualitatif. Bandung: PT Remaja Rosdakarya Offset.

Najati, Utsman. (2005a). Hadits dan Ilmu Jiwa. Bandung: Pustaka

Najati, Utsman. (2005b). Psikologi dalam al quran: Terapi qurani dalam penyembuhan gangguan kejiwaan. Bandung: Pustaka Setia

Nashori, F. (2005). Hubungan antara kualitas dan intensitas dzikir dengan kelapangdadaan mahasiswa. Millah, 5(1).

Pargament, K. I., Ensing, D., Falgout, K., Olsen, H., Reilly, B., Haitsma, K., \& Warren, R. (1990). God help me : ( I ): Religious coping efforts as predictors of the outcomes to significant negative life events. American Journal of Community Psychology, 18(6), 793824.

http://doi.org/10.1007/BF00938065

Patacchini, E., \& Zenou, Y. (2011). Social networks and parental behavior in the intergenerational transmission of religion. Bonn, Germany.

Petersen, A., \& Willig, R. (2002). An interview with Axel Honneth: The role of sociology in the theory of recognition. European Journal of Social Theory, 5(2), 265-277.

Philips, A. A. (2005). The Fundamentals of Tawheed. Riyadh: International Islamic Publishing House.

Poerwandari, E. K. (Ed.). (2005). Indonesian women in a changing society. Ewha Womans University Press.

Salleh, M. S. (2012). Religiosity in development: A theoretical construct of an islamic-based development. International Journal of Humanities and Social Science, 2(14), 266-274.

Simons, R. L., Beaman, J., Conger, R. D., \& Chao, W. (1993). Stress, support, and antisocial behavior trait as determinants of emotional well-being and parenting practices among single mothers. Journal of Marriage and Family, 55(2), 385.

Stalker, C. A., Mandell, D., Frensch, K. M., Harvey, C., \& Wright, M. (2007). Child welfare workers who are exhausted yet satisfied with their jobs: How do they do it?. Child \& Family Social Work, 12(2), 182-191. 
Stark, R. \& Glock, C. Y. (1968). American piety: The nature religious commitment. Barkeley dan Los Angeles: University of California Press.

Sullivan, S. C. (2008). Unaccompanied children in churches: Low-income urban single mothers, religion, and parenting. Review of Religious Research, 50(2), 157-175.

Tilliouine, H., \& Belgoumidi, A. (2009). An exploratory study of religiosity, meaning in life and subjective wellbeing in muslim students from Algeria. Applied Research Quality Life, 4, 109-127. http://doi.org/10.1007/s11482-0099076-8

Walpole, M. (2003). Socioeconomic status and college: How SES affects college experiences and outcomes. The Review of Higher Education, 27(1), 4573.

Wiley, A. R., Warren, H. B., \& Montanelli, D. S. (2002). Shelter in a time of storm: Parenting in poor rural African American Communities. Family Relations, 51(3), 265-273.

Wirawan, J. (2016, Februari 11). British Broadcast Company. Retrieved from Website British Broadcast Company: http://www.bbc.com/indonesia/berit a indonesia/2016/02/160210 indon esia_kemiskinan 